\title{
Peritonitis prevented in continuous ambulatory peritoneal dialysis by using the Hong Kong connection
}

\author{
RUSSELL D CLARK
}

\begin{abstract}
Based on the hypothesis that air contamination is an important cause of peritonitis in continuous ambulatory peritoneal dialysis, a simple and cheap connection system was developed whereby a clear polyethylene bag containing an antiseptic gauze was used as a sterilising chamber, effectively enclosing the connection procedure. Seven modifications to the connection technique were introduced over 32 months in 28 patients during 27.9 patient years of experience. The overall rate of peritonitis was 0.6 episode/patient year, but after a final modification at the beginning of the third year the rate fell to $0 \cdot 17$, without a single case of peritonitis occurring attributable to a connection failure in 11.5 patient years.

These findings show that in patients receiving continuous ambulatory peritoneal dialysis peritonitis may be prevented by enclosing the connection process and sterilising the introduced air and tubing ends.
\end{abstract}

\section{Introduction}

If peritonitis could be prevented continuous ambulatory peritoneal dialysis would be generally accepted as a long term therapeutic option for end stage renal disease. ${ }^{1}$ Entry of bacteria into the sterile peritoneal cavity occurs primarily at the time of connection of each new dialysis bag, a process which occurs some 1250 times a year. The standard procedure for connection relies on a skilled, no touch technique using a quick killing antiseptic (usually povidone-iodine) in various ways to sterilise appropriate end points. The technique is open and performed in the ordinary environment.

Carelessness and non-compliance with the technique are generally considered to be the major reasons for the development of peritonitis. Despite intensive training and high motiva-

\footnotetext{
Department of Medicine, United Christian Hospital, Kwun Tong, Hong Kong

RUSSELL D CLARK, FRACP, DTM\&H (SYD), consultant and head of department of medicine
}

tion, however, it was apparently impossible to reduce the rate of peritonitis to below 0.4 episode/patient year ( $1 / 2.5$ patient years) in one centre, ${ }^{2}$ although in most centres the rate is 1-2 episodes/patient year. ${ }^{3-7}$

Based on the hypothesis that peritonitis occurs in continuous ambulatory peritoneal dialysis because of contamination by air at the time of connection a new method of connection has been developed-the "Hong Kong connection"-in which there is only one connection to be made, and this is performed within a sterile enclosed environment. This paper reports on the experience gained in using this technique, with special attention to assessing its ability to prevent peritonitis.

\section{Patients and methods}

Consecutive Chinese patients were admitted to the dialysis programme once they were in established end stage renal failure due to primary renal disease, mainly chronic glomerulonephritis with bilaterally contracted kidneys. Local policy enforced geographical and age limits. Locally the choice was long term peritoneal dialysis or death, as there was no access to haemodialysis. Twenty eight consecutive patients were established on continuous ambulatory peritoneal dialysis over the 32 months September 1980 to May 1983, comprising 15 men and 13 women aged 22-52. Patients came from the lower socioeconomic classes with limited education, eight being illiterate.

Institution of treatment and patient training-Tenckhoff double cuffed catheters were implanted under local anaesthesia and continuous ambulatory peritoneal dialysis established. Patients were individually trained by the nursing staff.

Hong Kong connection-A batch of 24 sterilising bags were made each week by each patient by inserting pieces of gauze soaked in antiseptic into transparent, thin polyethylene bags and sealing the opening with a heat sealer. The connection procedure (fig 1) consisted initially in inserting the capped connecting tubing through a small incision in one corner of the sterilising bag, sealing the entrance with tape, and wrapping the gauze piece around the end for a timed five minutes. A similar opening was then made diagonally opposite and the sterilising bag fitted over the capped Tenckhoff catheter, similarly sealed with tape, and wrapped in the antiseptic gauze for a second timed five minutes. The connecting tubing and Tenckhoff catheter were clamped, caps removed, and the antiseptic gauze repositioned to sterilise the exposed ends for a third timed five minutes. The ends were then pushed together, the caps submerged in a pool of antiseptic inside the sterilising bag, the bag wrapped neatly around 
the connected tubing, and the peritoneal dialysis fluid run inside. Disconnection consisted in capping the Tenckhoff catheter within the sterilising bag and then withdrawing it from the bag. In experienced hands the whole exchange process, including fluid running in and out, took $\mathbf{4 0}$ minutes.

Peritonitis was diagnosed on the basis of clinical features, increased cell counts in the dialysis effluent $\left(>100 \times 10^{6} / 1\right)$, and culture of dialysis effluent in thiol broth. Management consisted of admission, initial lavage with intraperitoneal antibiotics (cloxacillin $50 \mathrm{mg} / \mathrm{l}$, gentamicin $8 \mathrm{mg} / \mathrm{l}$ ) until culture results were available, and then continuation with appropriate antibiotics for a further four weeks. The catheter was removed as appropriate. were established (table II). In four cases there was a fault in the catheter, in two a fault in the catheter bed, and in one a fault in the dialysis fluid (introduced bacteria); in three no fault could be found, and these were labelled as "connection failure." In three cases there was non-compliance in performing the technique, in three infection occurred while using a modified Travenol system, and in one there was a bowel perforation related to the location of the Tenckhoff catheter.

As each fault was detected modifications were introduced (fig 2). In all, seven modifications were introduced during the study period. Catheter bed faults occurred in two cases, requiring two modifications - (a) and (e) (fig 2)-which successfully prevented recurrence from
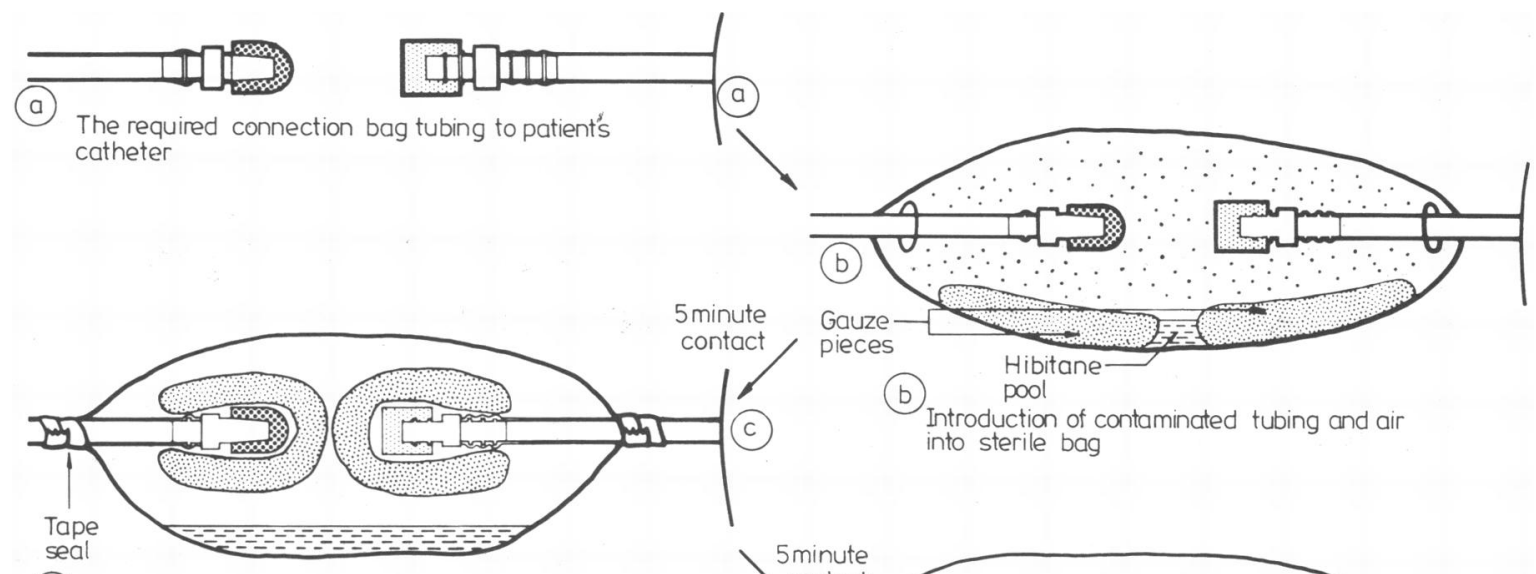

into sterile bag

Distal capped tubing ends and air sterilised with sealed sterilising bag
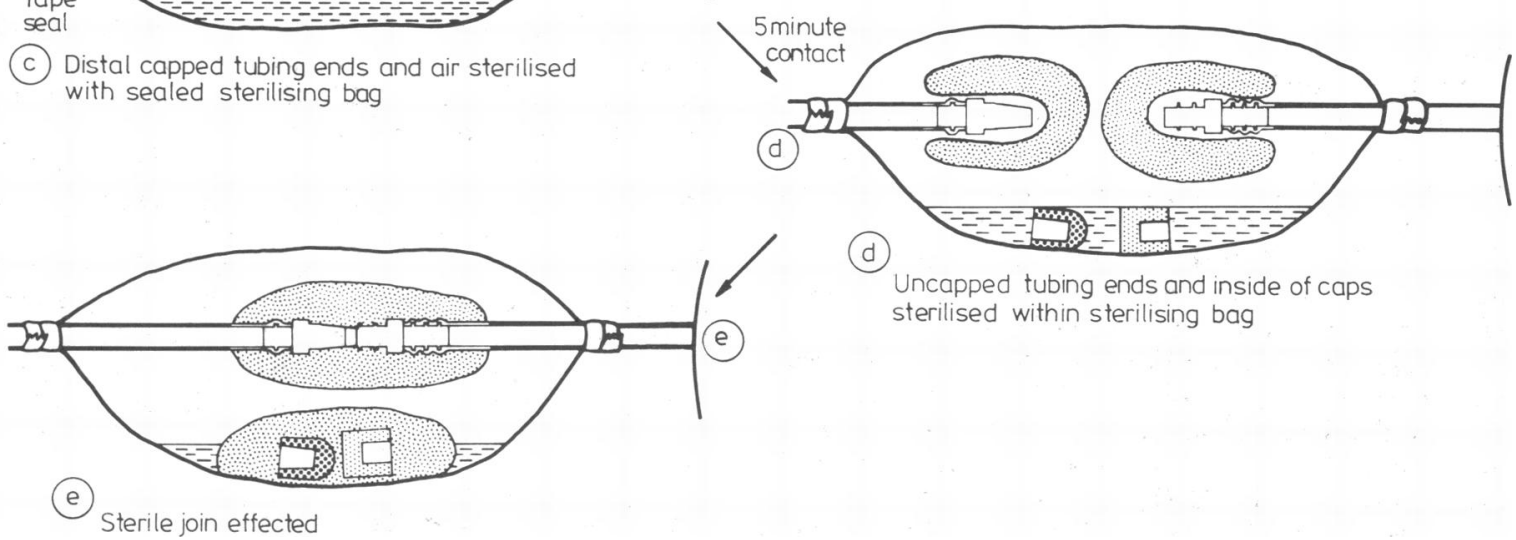

FIG 1-Major steps in performing Hong Kong connection.

Bags for continuous ambulatory peritoneal dialysis were supplied by Japan Medical Supply(s) and consisted of 2 litre $2.5 \%$ peritoneal dialysis solutions in plastic bags. Four exchanges six days a week was the standard method employed. Patients recorded data of exchange in their own dialysis book, the illiterate patients being taught how to do this.

\section{Results}

Of the 28 patients established on a continuous ambulatory peritoneal dialysis programme over the 32 months (fig 2 ), 22 remained well maintained at the end of the study period. Among the others, however, there were two deaths $(7 \%$; both related to peritonitis with subsequent complications) and four cases $(14 \%)$ of failure of peritoneal dialysis, requiring transfer to haemodialysis. Of the four failures, three were related to prolonged or severe bacterial peritonitis and one to a persistent haemoperitoneum after repositioning of a blocked Tenckhoff catheter. Twelve patients received continuous ambulatory peritoneal dialysis for more than one year and three for more than two years. The median duration for all patients was 42 weeks, and the total duration of treatment was 1452 patient weeks (27.9 patient years).

Each of the 17 episodes of peritonitis was analysed to establish the mode of bacterial entry (table I). In all, seven distinct mechanisms

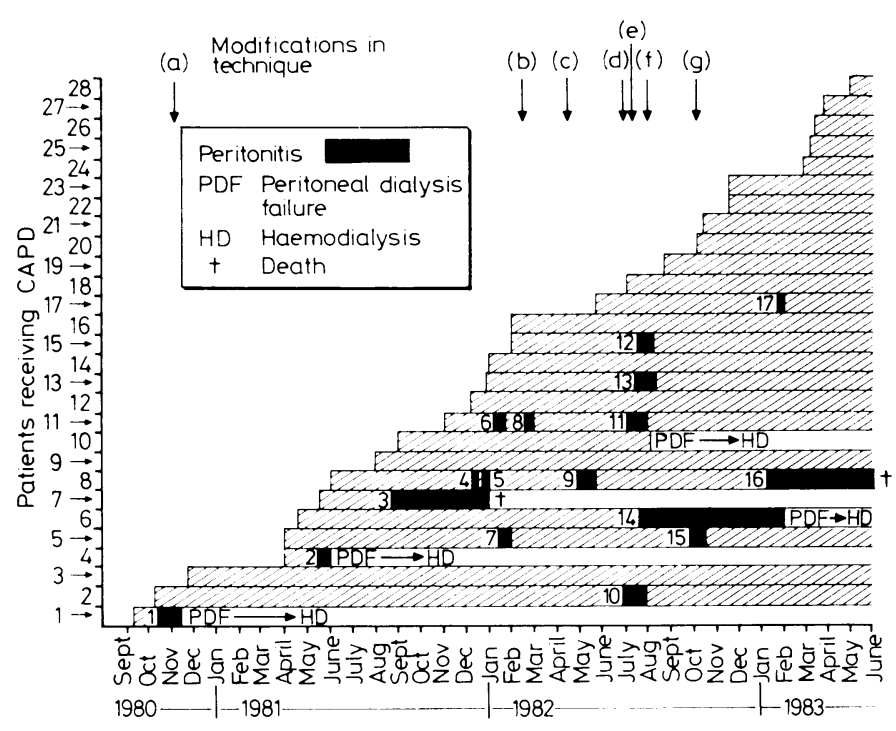

FIG 2-Peritonitis and outcome of patients established on continuous ambulatory peritoneal dialysis (CAPD) using Hong Kong connection. 
these causes. Modification ( $a$ ) insisted that the patient should remain seated during outflow of the dialysate, as traction stress ruptured fibrous bonds without extrusion of the catheter, allowing bacterial access along the catheter in one patient. Modification (e) related to a more careful placement of the Tenckhoff catheter and early definitive surgical repair for localised skin ulcers related to the subcutaneous section of the catheter. Exit wounds occurred infrequently (six cases) and did not lead to peritonitis in any case.

An important cause of peritonitis in the first 18 months related to faults developing in the Tenckhoff catheter. Before March 1982 there were seven separate episodes of fracture of the Silastic tubing. In five the fracture was obvious (in two cases the tubing was broken into two) but appropriate clamping and prompt replacement prevented peritonitis. In two, however, the fracture was small and not detected until after peritonitis had developed. Inspection of the tubing in all patients showed that the tubing in contact with the povidone-iodine had become discoloured, thin, and brittle. This also applied to the rubber cap, which perished in one case. The antiseptic was changed to chlorhexidine (Hibitane in spirit). We also found that the rubberised arterial clamp used to clamp the catheter was too severe on Silastic tubing and a softer clamp was used. On one occasion the connector piece was accidentally clamped, causing it to fracture. Before these modifications there were nine instances of catheter damage in 412 patient weeks, four leading to peritonitis; after these modifications $(b)$ in March 1982, however, there was no instance of catheter damage in 1042 patient weeks (20 patient years) and consequently no further peritonitis from this cause.

Fluid fault was a problem in just one patient; to stay in fluid balance he required a higher concentration of glucose in his dialysis fluid than would be achieved with the standard $2.5 \%$ solution supplied. For six months $50 \%$ glucose was added to two of his dialysis bags each day, but Staphylococcus aureus was introduced in April 82. Subsequently no additions of any chemicals were made to any patient's bags (modification $c$ ).

For two weeks in July 1982 a further modification $(f)$ was tried. Seven patients, all well established on continuous ambulatory treatment, were changed to using Travenol dialysis bags and tubing. An attempt was made to incorporate the sterilising bag between the dialysis bag outlet and the connecting tubing spike, and patients were appropriately trained. Staph epidermidis, however, was introduced in three patients within two weeks and all were returned to the previous system. Bacterial entry probably occurred because of unnoticed puncturing of the sterilising bag by the tubing stylet, with contamination from the exterior of the bag.

On three occasions in two patients there was frank non-compliance with the technique of connection, despite adequate skills and proved competence. The reactions in each case were extreme and construed as rebellion in one patient and panic in the other.

In three patients on three occasions no obvious fault was detectable in the catheter or technique and these cases were labelled as connection failure. On review analysis of the connection, however, we realised that the rubber cap on the Tenckhoff catheter had to be correctly fitted to prevent entry of bacteria beneath the cap, as this was a protected area not touched by antiseptics yet offering entry to the catheter lumen. Loss of elasticity of the rubber cap allowed skew placement, and modification $(d)$ introduced a change of cap every four months, careful attention to correct placement, and submerging of the cap in a pool of antiseptic between exchanges (fig 1). A further weakness related to the fact that the proximal segments of the tubing inside the sterilising bag were not sterilised (fig 1) and excessive manipulation allowed direct contact occasionally between an uncapped Tenckhoff catheter and the contaminated proximal segment. Modification $(g)$ was the use of two pieces of gauze for each sterilising bag, allowing separation of the two ends at all times.

The overall rate of peritonitis, including all causes, during the study period was 1 episode/ 85 patient weeks or 0.6 episode/patient year. The overall rate of peritonitis from connection failure alone was 1 episode/484 patient weeks ( $9 \cdot 3$ patient year) or $0 \cdot 1$ episode/patient year. The combined rate of peritonitis from connection failure and non-compliance was 1 episode/242 patient weeks, or $0 \cdot 2$ episode/year. After the final modification in October $1982(g)$ the peritonitis rate was 1 episode/300 patient weeks, or 0.17 episode/year, and not a single connection failure occurred in 11.5 patient years.

Life table actuarial analysis was performed (fig 3) assessing the probability of developing a first episode of peritonitis for patients entered into the programme during the first, second, and third years. The probabilities were significantly reduced for each year, no episodes of peritonitis developing in the nine patients entered in the third year to the end of the study period.

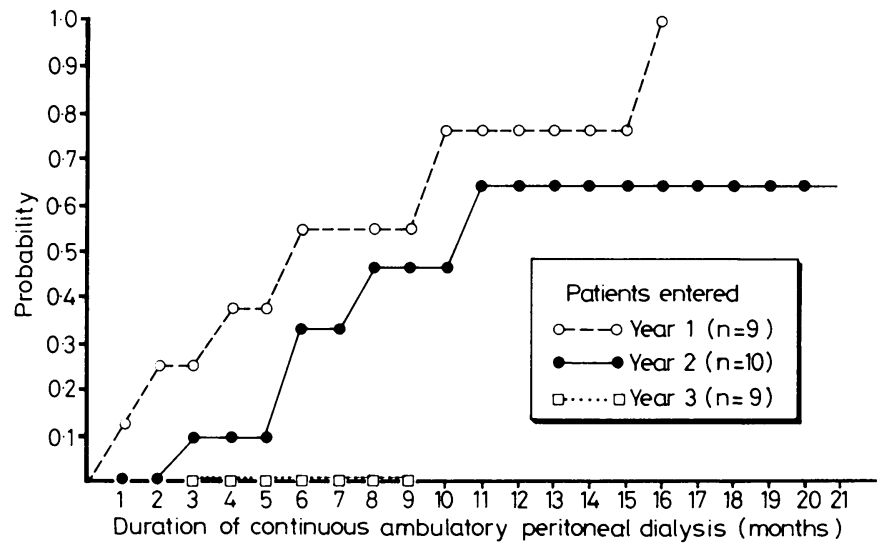

FIG 3-Probability of developing first episode of peritonitis using life table analysis method for each year of entry.

TABLE I-Details of episodes of peritonitis in 11 patients affected

\begin{tabular}{|c|c|c|c|c|c|}
\hline $\begin{array}{l}\text { Peritonitis } \\
\text { episode }\end{array}$ & Date & Organism & Mechanism of peritonitis & $\begin{array}{c}\text { Response to } \\
\text { treatment }\end{array}$ & Outcome \\
\hline 1 & $9 / 10 / 80$ & No growth & Catheter bed fault-ruptured fibrous bonds & Failure & $\mathrm{HD}$ \\
\hline & $11 / 5 / 81$ & $\begin{array}{l}\text { Pseudomonas } \\
\text { Stidis }\end{array}$ & Catheter fault-fracture & Failure & HD \\
\hline $\begin{array}{l}3 \\
4\end{array}$ & $\begin{array}{l}15 / 8 / 81 \\
3 / 12 / 81\end{array}$ & $\begin{array}{l}\text { Staph epidermidis } \\
\text { No growth }\end{array}$ & $\begin{array}{l}\text { Connection failure } \\
\text { Catheter fault-perished cap }\end{array}$ & $\begin{array}{l}\text { Failure } \\
\text { Ouick }\end{array}$ & Death \\
\hline 5 & $19 / 12 / 81$ & No growth & Catheter fault-connector fracture & Quick & CAPD \\
\hline 6 & $6 / 1 / 82$ & No growth & Non-compliance-rebellion & Quick & CAPD \\
\hline 7 & $16 / 1 / 82$ & No growth & Catheter fault-fracture & Quick & CAPD \\
\hline $\begin{array}{l}8 \\
9\end{array}$ & $\begin{array}{l}13 / 2 / 82 \\
24 / 4 / 82\end{array}$ & $\begin{array}{l}\text { No growth } \\
\text { Staph aureus }\end{array}$ & $\begin{array}{l}\text { Non-compliance-rebellion } \\
\text { Fluid fault-introdyced }\end{array}$ & Slow & CAPD \\
\hline $\begin{array}{r}9 \\
10\end{array}$ & $\begin{array}{l}20 / 6 / 82 \\
20 / 4 / 82\end{array}$ & $\begin{array}{l}\text { Staph aureus } \\
\text { Staph epidermidis }\end{array}$ & $\begin{array}{l}\text { Fluid tautit }- \text { introduced } \\
\text { Connection failure }\end{array}$ & $\begin{array}{l}\text { Slow } \\
\text { Slow }\end{array}$ & CAPD \\
\hline 11 & $7 / 7 / 82$ & Staph epidermidis & Catheter bed fault-chronic sinus tract & Slow & CAPD \\
\hline 12 & $15 / 7 / 82$ & Staph epidermidis & Modified Travenol & Slow & CAPD \\
\hline $\begin{array}{l}13 \\
14\end{array}$ & $16 / 7 / 82$ & $\begin{array}{l}\text { Staph epidermidis } \\
\text { Stan }\end{array}$ & Modified Travenol & $\begin{array}{l}\text { Slow } \\
\text { Failure }\end{array}$ & CAPD \\
\hline 15 & $\begin{array}{l}1997 / 82 \\
27 / 9 / 82\end{array}$ & $\begin{array}{l}\text { Staph epidermidis } \\
\text { Staph epidermidis }\end{array}$ & $\begin{array}{l}\text { Modithed Travenol } \\
\text { Connection failure }\end{array}$ & $\begin{array}{l}\text { Fallure } \\
\text { Quick }\end{array}$ & ${ }_{\text {CAPD }}^{\text {HD }}$ \\
\hline 16 & $7 / 1 / 83$ & Pseudomonas & Bowel perforation & Failure & Death \\
\hline 17 & $13 / 2 / 83$ & Bacillus & Non-compliance-panic & Quick & CAPD \\
\hline
\end{tabular}

$\mathrm{HD}=$ Haemodialysis $. \mathrm{CAPD}=$ Continuous ambulatory peritoneal dialysis.

TABLE II-Summary of mechanisms of 17 episodes of peritonitis during study period

\begin{tabular}{|c|c|c|c|c|c|c|c|}
\hline & Catheter fault & Catheter bed fault & Fluid fault* & Connection failure & Non-compliance & Modified Travenol & Bowel perforation \\
\hline No of episodes & 4 & 2 & 1 & 3 & 3 & 3 & 1 \\
\hline
\end{tabular}

- Introduced bacteria. 


\section{Discussion}

Peritonitis was not completely prevented by the Hong Kong connection technique, but the overall rate was low at 0.6 episode/patient year. Analysis of the causes of peritonitis, however, showed that this occurred in seven cases where the technique could not be incriminated (catheter bed fault (two), introduced bacteria (one), modified Travenol technique (three), bowel perforation (one)) and in another four cases where the technique itself led to unexpected damage and subsequent peritonitis directly as a consequence of this damage. It seems reasonable to consider only the compliance problems and the connection failures as being truly representative of the technique, and this gave an overall rate of 0.2 episode/patient year during the study.

Seven modifications were introduced during the study and proved successful, thus confirming the correctness of the original analysis. This was most obvious with catheter faults, catheter bed faults, and dialysis fluid faults. The poor results with the modified Travenol system do not reflect on that system but simply show that the sharp spike of the connecting tubing makes it impossible to use the sterilising bag. Direct contact of stylet with external surface of the sterilising bag was far more hazardous than an open, but no touch, system of connection.

It is impossible to know the exact mechanism of the peritonitis in the three cases considered to be connection failures. Nevertheless, after the introduction of two modifications not a single case of peritonitis attributable to the connection technique occurred in more than 11 patient years, suggesting that the weak points had been identified and corrected.

Only two patients failed to comply, and in each case there were extreme circumstances. In fact, compliance with the technique was remarkably high. This is the more noteworthy when it is appreciated that the patients had little understanding of "germ theory" and Western medicine; were of limited educational standing (two had to be taught to tell the time and eight to write figures); lived in cramped, overcrowded apartments (35 square feet $\left(3.25 \mathrm{~m}^{2}\right)$ is the total space allowance per person) in the housing estates of Hong Kong; and did not receive supervisory visits at home. The technique was in fact quickly learnt and faithfully performed in some 35000 separate connections.

The Hong Kong connection may not be elaborate but it has proved to be effective, simple, cheap, easily learnt, and easily applied. The clear plastic bag allows manipulation visually, provides the enclosed sterile space, and with the chlorhexidine brings about sterilisation both of the air and of the ends of the tubing. This study supports the hypothesis that air contamination is an important cause of peritonitis in continuous ambulatory peritoneal dialysis and that to prevent peritonitis in these patients it is necessary to enclose the connection process with sterilisation of introduced air and tubing ends.

Dr A S P Hua, formerly of the Department of Medicine, University of Hong Kong, conceived both the hypothesis of air contamination and the method of connection.

I thank the nurses of ward 2C, especially Sister J Wong, for their able help and the doctors in the department of medicine for their support.

An illustrated manual on the Hong Kong connection is available on request.

\section{References}

${ }^{1}$ Rasheed A, Goldsmith HJ. Hospital at home, home dialysis. Br $\mathcal{F}$ Hosp Med 1983;29:95-104.

2 Gorey P. An approach to the statistical analysis of peritonitis data from patients on CAPD. Peritoneal Dialysis Bulletin 1981;1:29-32.

${ }^{3}$ Prowant B, Nolph KD. Five years' experience with peritonitis in a CAPD program. Peritoneal Dialysis Bulletin 1982;2:169-70.

4 Gokal R, Ramos JM, Francis DMA, et al. Peritonitis in continuous ambulatory peritoneal dialysis. Lancet 1982 ;ii:1388-91.

${ }^{5}$ Gloor HJ, Nichols WK, Sorkin MI, et al. Peritoneal access and related complications in continuous ambulatory peritoneal dialysis. Am $\mathcal{F} \mathrm{Med}$ 1983;74:593-8.

${ }^{6}$ Rigby RJ, Buttler JL, Petrie JJB. Experience with continuous ambulatory peritoneal dialysis. Med $\mathcal{F}$ Aust $1982 ; \mathrm{i}: 331-5$.

${ }^{7}$ Kincaid-Smith P, Becker G. Continuous ambulatory peritoneal dialysis. Med $\mathcal{F}$ Aust 1982;i:325-6.

(Accepted 25 October 1983)

\title{
Prognosis after myocardial infarction: results of 15 year follow up
}

\author{
MARGARET A MERRILEES, P JOHN SCOTT, ROBIN M NORRIS
}

\begin{abstract}
A total of 271 out of 757 patients who had suffered a myocardial infarction during 1966-7 were still alive after six years; these patients were subsequently followed up 15 years after the infarction. Two hundred and sixty eight $(99 \%)$ of the patients alive at six years and 519 $(95 \%)$ of the 549 originally discharged from hospital were traced. A coronary prognostic index, which had predicted survival both to three years and from three
\end{abstract}

\footnotetext{
Department of Medicine, University of Auckland School of Medicine, Auckland, New Zealand

MARGARET A MERRILEES, BSC, graduate research assistant

P JOHN SCOTT, MD, FRCP, professor and head of department

Coronary Care Unit, Greenlane Hospital, Auckland

ROBIN M NORRIS, MD, FRCP, physician in charge

Correspondence to: Professor P J Scott.
}

to six years after recovery from the infarct also predicted survival from six to 15 years after recovery. The major factor affecting survival to 15 years was age at the time of the original infarct. Among patients aged under 60 at the time of infarction women fared better than men ( $p=0.027)$. Factors in the coronary prognostic index that were associated with impairment of left ventricular function at the time of infarction and that had predicted mortality to three years and from three to six years also predicted mortality from six to 15 years. These factors were cardiac enlargement, pulmonary venous congestion, and the presence of infarction before the index infarct. The dominant cause of death remained coronary heart disease and its complications.

\section{Introduction}

From March 1966 to February 1967, 757 patients with acute myocardial infarction were admitted to the three general 